\title{
Andrea Pozzo \\ e l'arte dei linguaggi scenici
}

\author{
Leonardo Baglioni \\ Marta Salvatore
}

Abstract

II contributo intende esplorare le forme di rappresentazione scenografica nell'opera di Pozzo, con particolare riferimento alla scenografia teatrale. Principio pedagogico fondativo nell'ambito della Compagnia di Gesù, il teatro gesuitico barocco si rende strumento di persuasione e veicolo di condivisione collettiva dei messaggi della cristianità, acquisendo un ruolo centrale nella formazione. La scenografia teatrale si pone dunque in continuità ideologica con le finalità pedagogiche alla base dell'idea di scenografia che anima tutta l'opera di Pozzo, continuità che trova riscontro anche nella pratica prospettica. Se il teatro gesuitico si discosta in termini di contenuto dal teatro di spettacolo di quegli anni, condivide con esso impianto, macchineria e apparati scenici. Poco sappiamo dell'attività di Pozzo come scenografo teatrale, eppure il suo contributo appare fondamentale nella storia dell'evoluzione dello spazio scenico letta in chiave prospettica, perché testimonia una pratica scenografica in anni in cui il teatro barocco aveva acquisito una sua matura configurazione. II teatro scenico si distingue inoltre dal resto della trattazione perché presenta una serie di criticità procedurali introdotte dall'obliquità dei 'telari', che Pozzo sapientemente risolve con consapevolezza proiettiva e rigore metodologico.

Parole chiave

Andrea Pozzo, scenografia, teatro, prospettiva, graticolazione.

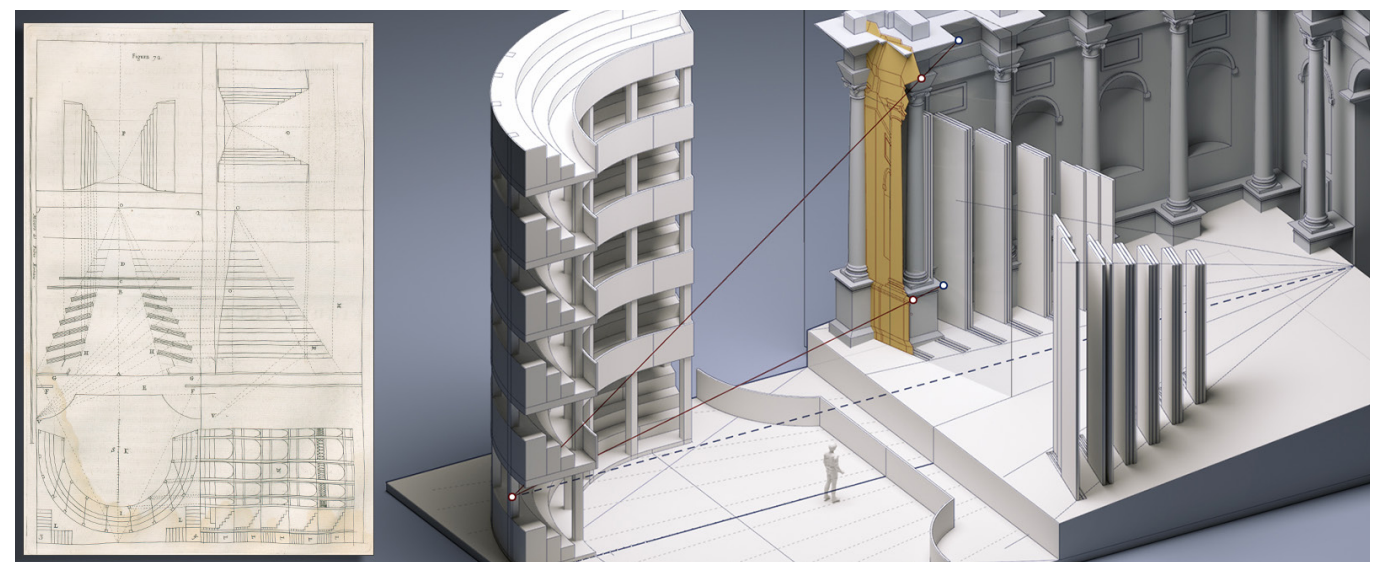




\section{Linguaggi scenici e scenografia teatrale}

Nella Perspectiva pictorum et architectorum pubblicata in due volumi nel 1693 e nel I700, Pozzo riversa memoria delle opere che realizza e che descrive in termini spiccatamente operativi alla maniera manualistica in uso al tempo. I due volumi del trattato insegnano al lettore, non necessariamente esperto della materia, a costruire la prospettiva e a impiegarla per la realizzazione di applicazioni notevoli di cui il suo operato è ampiamente testimone. Nel contesto generale di una trattazione a stampa che ricalca la propria produzione artistica, trovano quindi spazio modelli grafici di prospettive applicate, riferibili alle prospettive architettoniche, a piombo o "di sotto in su" e alle prospettive dei 'telari' di cui si compongono i teatri liturgici, realizzati per le celebrazioni religiose delle Quarantore. In questo stesso contesto si inserisce, in entrambi i volumi del trattato, la scenografia teatrale, che si distingue dalle altre configurandosi, rispetto a queste, particolarmente significativa.

L'idea di scenografia interessa in generale l'arte figurativa di Pozzo, che si sviluppa nella cultura della performance e dello spettacolo del XVII secolo. Scenografiche sono infatti le quadrature da lui realizzate e altrettanto scenografici appaiono i 'telari' che compongono le scene dei teatri liturgici [Baglioni 2019, pp. 317-324]. Questa idea trasversale di scenografia, intesa nella sua accezione prospettica più ampia, trova riscontro anche da un punto di vista strettamente proiettivo. Molte delle opere di Pozzo sono infatti composizioni di prospettive, capaci di restituire l'illusione se osservate simultaneamente dal corretto centro di proiezione, secondo un principio di aggregazione di prospettive lineari realizzate su piani di quadro diversamente orientati, caratteristiche degli impianti scenici del teatro sin dalle sue prime configurazioni rinascimentali [Baglioni, Salvatore 20 I 8, pp. 4I-52]. Ma le relazioni fra le prospettive architettoniche, il teatro liturgico e il teatro scenico affondano le proprie radici nella finalità pedagogica ed educativa che anima le realizzazioni pittoriche gesuitiche di quegli anni e che vede nell'azione sinergica della retorica visiva e della performance uno strumento di persuasione e azione formativa di giovani e fedeli [Horn 2019, pp. 216, 217]. Praticato in collegi e seminari ma non solo, il teatro gesuita si poneva come alternativa pedagogica allo spettacolo laico barocco allora in voga, prendendone le distanze in termini di contenuto ma condividendo con esso impianto, macchineria e apparati.

Non abbiamo informazioni dettagliate circa l'attività di Pozzo come scenografo teatrale se non che fu attivo a Milano e a Venezia [Horn 2019, p. 221] e che nel periodo trascorso a Roma, secondo quanto racconta il Pascoli, realizzò tre cambi di scena per il teatro del Seminario Romano [Pascoli I736, p. 264].

Fig. I. Teatro ideale di Andrea Pozzo e parti di cui si compone, Figura 72 del primo libro dell'edizione del 1693 [Pozzo dizione
1693].
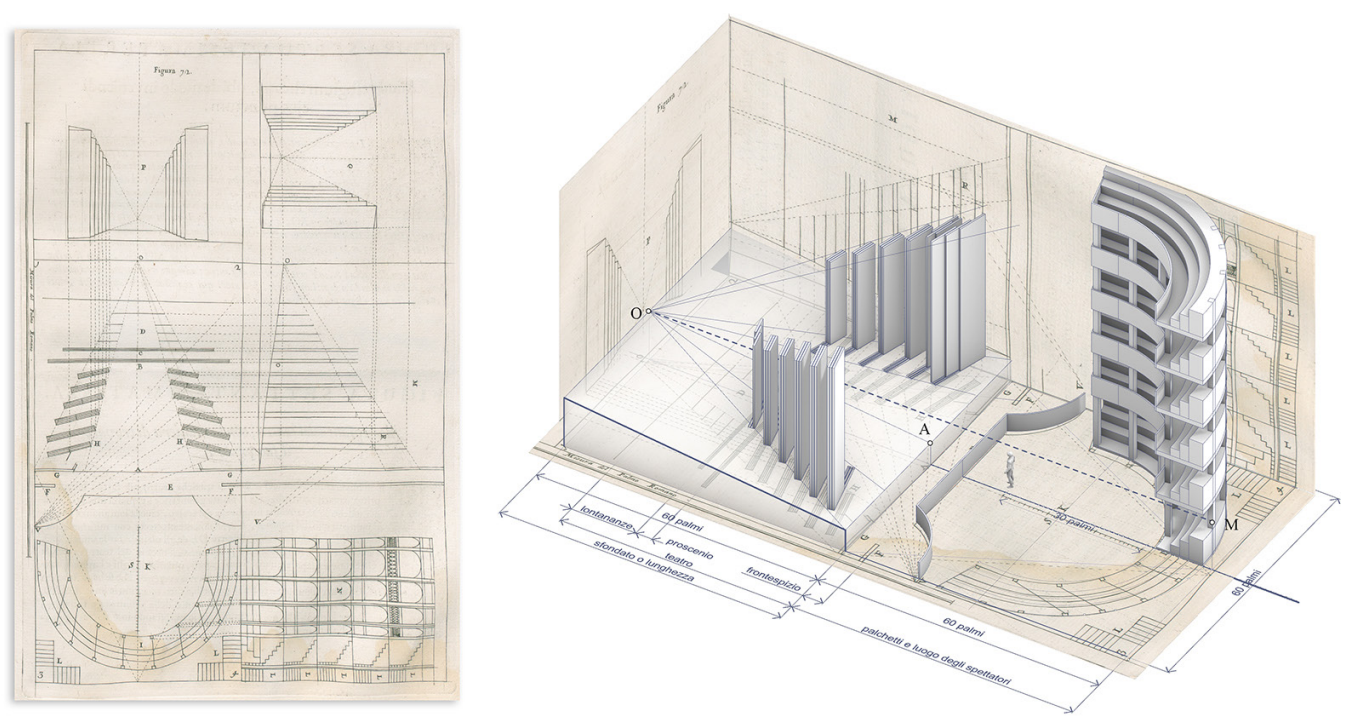
Tuttavia, le pagine del trattato dedicate al 'teatro scenico' testimoniano la piena consapevolezza di una prassi operativa che era andata consolidandosi nel corso di tutto il XVII secolo e costituiscono una testimonianza particolarmente preziosa, in termini di consistenza e collocazione temporale. II contributo di Pozzo è infatti espressione di una configurazione matura dell'impianto scenico del teatro barocco che sarebbe stato in quegli anni rivoluzionato dall'introduzione bibienesca del modello prospettico d'angolo.

\section{La pratica prospettica nell'arte della costruzione delle scene}

Nel commento alla figura 72 del volume del 1693, dopo aver illustrato la maniera di costruire i teatri liturgici, Pozzo introduce, in assoluta continuità, il tema dei 'teatri scenici'. Da un punto di vista prospettico e costruttivo questi teatri si avvalgono di apparati scenografici affini, composti entrambi da un insieme di prospettive lineari viste dal medesimo centro di proiezione e realizzate su 'telari' distinti. Se i teatri liturgici, per lo più immobili, trovavano generalmente collocazione nelle chiese, in luogo degli altari, ponendosi in continuità con l'architettura esistente, $i$ 'teatri scenici' di quegli anni si configurano come un organismo edilizio a sé stante, capace di ospitare scenografie dinamiche che si rinnovano più volte e che rispondono a una configurazione spaziale propria e predeterminata dell'edificio teatrale. La complessità insita nella mutevolezza dell'apparato scenico in relazione ai vincoli dati dall'edificio teatrale che la ospita, sono i principali elementi che differenziano il 'teatro scenico' da quello liturgico.

La scena barocca è dinamica e durante uno stesso spettacolo sono molti i cambi di scena da eseguire [Mancini 1966, p. 49]. Così i 'telari' che portano le scene sono inseriti in canali, feritoie realizzate sul piano del palco, capaci di accoglierne più d'uno e di farli scorrere gli uni sugli altri per rispondere nella maniera più rapida ed efficiente ai repentini cambi di scena [Povoledo 1979, pp. I0, I I]. Nella prassi scenografica del tempo si ricorreva a canali paralleli al fronte della scena oppure paralleli fra loro ma obliqui rispetto al fronte, secondo un modello in uso nel teatro all'italiana a cui Pozzo fa esplicito riferimento. La disposizione

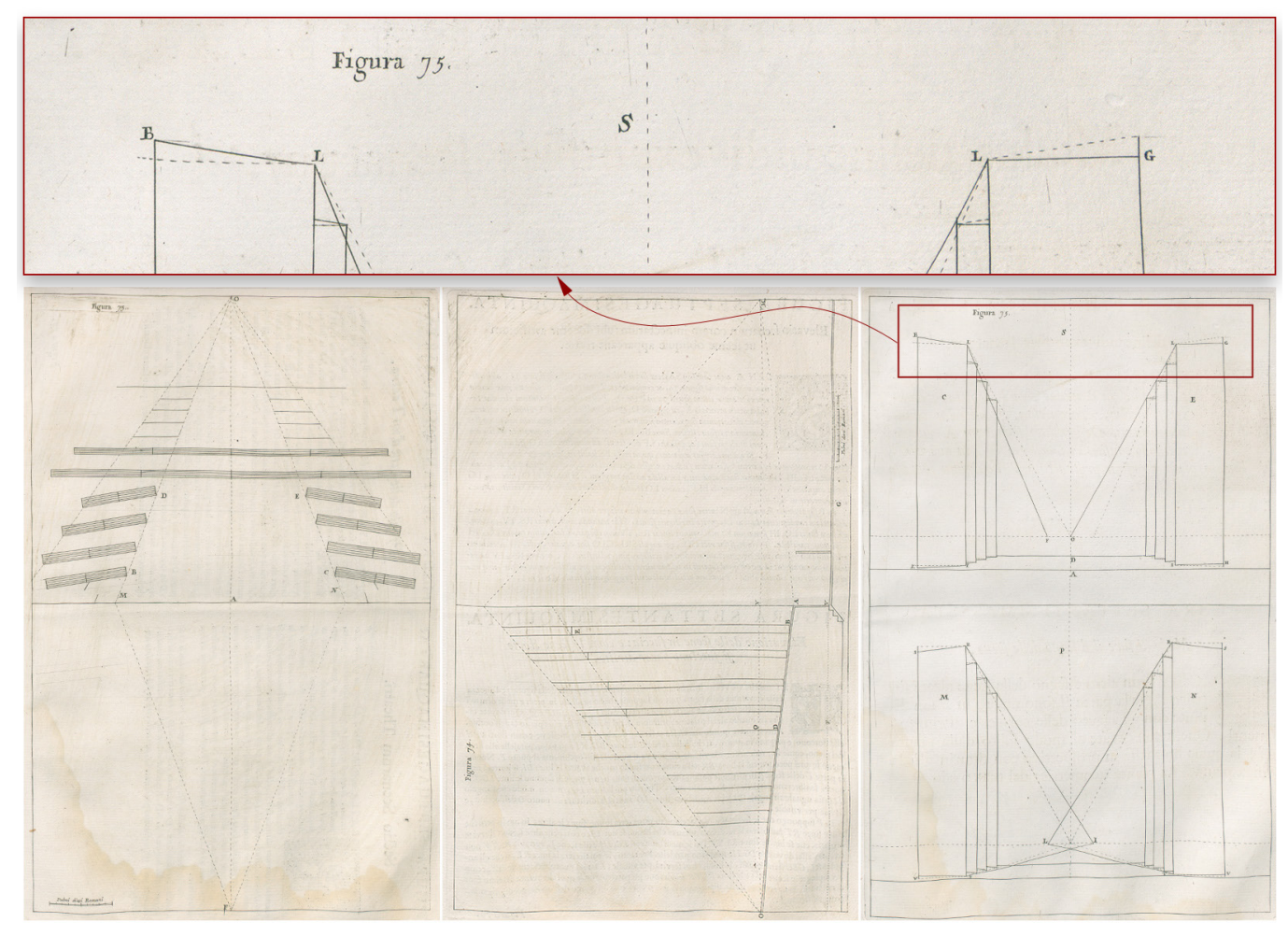


Fig. 3. Individuazione del punto di fuga delle rette parallele al fronte dell scena secondo un approccio proiettivo. In alto a sinistra il quadrilatero in vera forma della prima quinta della scena.
Fig. 4. Individuazione del profilo dei 'telari' secondo l'approccio operativo di Pozzo che fa uso della rappresentazione in fezione. 74 del a destra [Pozzo 1693]. [Pozzo 1693].

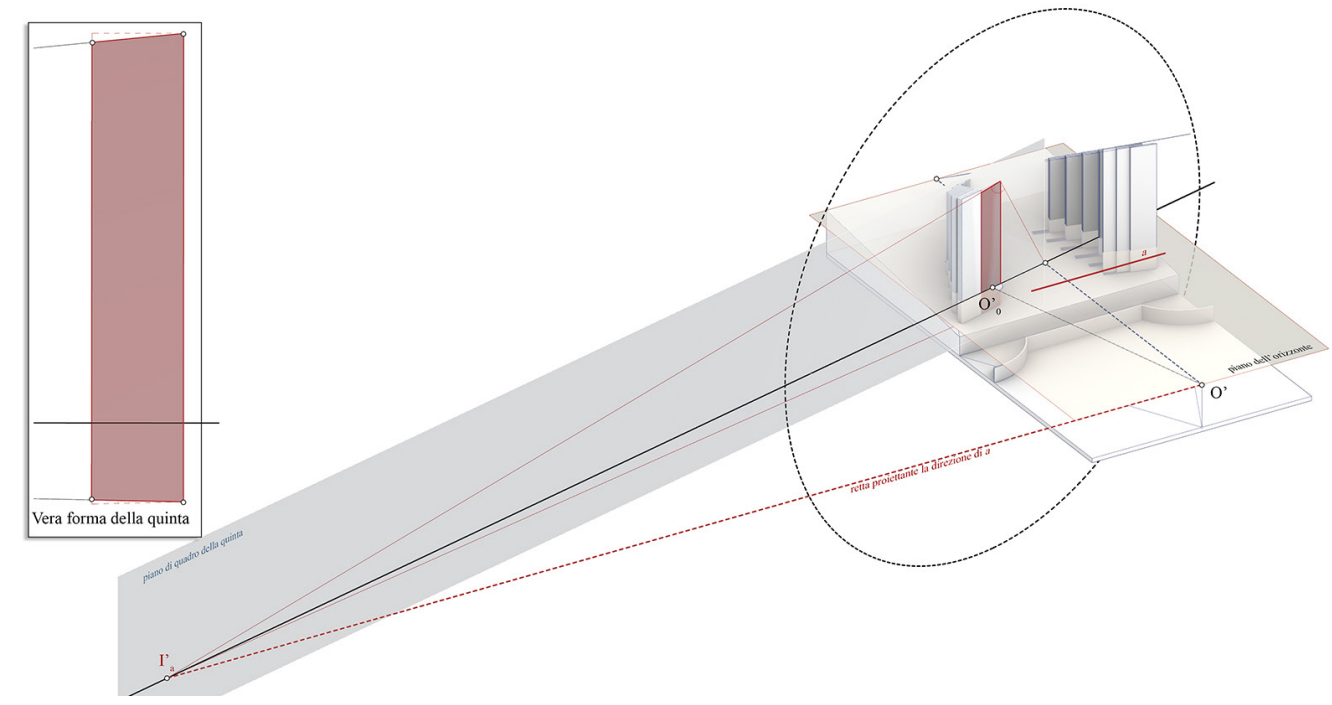

dei canali influenzava in maniera determinante l'impianto prospettico della scena, in particolare se la loro disposizione era obliqua. Se ne doveva tenere conto in fase di progettazione dell'edificio teatrale $\mathrm{o}$ in fase di progettazione della scena nel caso di teatri già realizzati. In entrambi i volumi del trattato Pozzo considera tanto i canali paralleli quanto quelli obliqui, ma sono questi ultimi a dettare condizioni che vincolano l'impianto prospettico nel suo insieme e, a questo assetto, è dedicata la parte più consistente della trattazione [ I]. II taglio operativo e sperimentale, che permea l'opera di Pozzo, si palesa con estremo vigore nelle pagine dedicate agli apparati scenici. A differenza di altre proposizioni caratterizzate da esattezza e rigore metodologico, il 'teatro scenico' presenta diversi passaggi di difficile interpretazione e alcune incoerenze grafiche. Pertanto, l'analisi critica interpretativa che segue risulta dall'integrazione della lettura filologica del testo e dei suoi apparati grafici con le pratiche prospettiche in uso al tempo.

Per comprendere appieno il significato dei procedimenti descritti si è costretti a calarsi nei panni di chi le prospettive delle scene avrebbe dovuto effettivamente dipingerle, all'interno del teatro, riverse sul piano del palco, dove la costruzione doveva necessariamente soddisfare il rigore e la rigidità caratteristiche della produzione prospettica di Pozzo.

La trattazione inizia, nel primo libro, con un'attenta descrizione degli elementi di cui si compone l'edificio teatrale e delle sue dimensioni ideali. Parte dell'edificio è considerato il cosiddetto "punto dell'occhio del teatro", punto di fuga degli spigoli della scatola scenica contratta ortogonali al fronte della scena (fig. I). In una scenografia a canali obliqui la posizione di questo punto è fissa, e risulta dall'intersezione delle 'linee visuali' che giacciono sul piano inclinato del palco e che lambiscono i canali verso l'interno della scena. II 'punto della

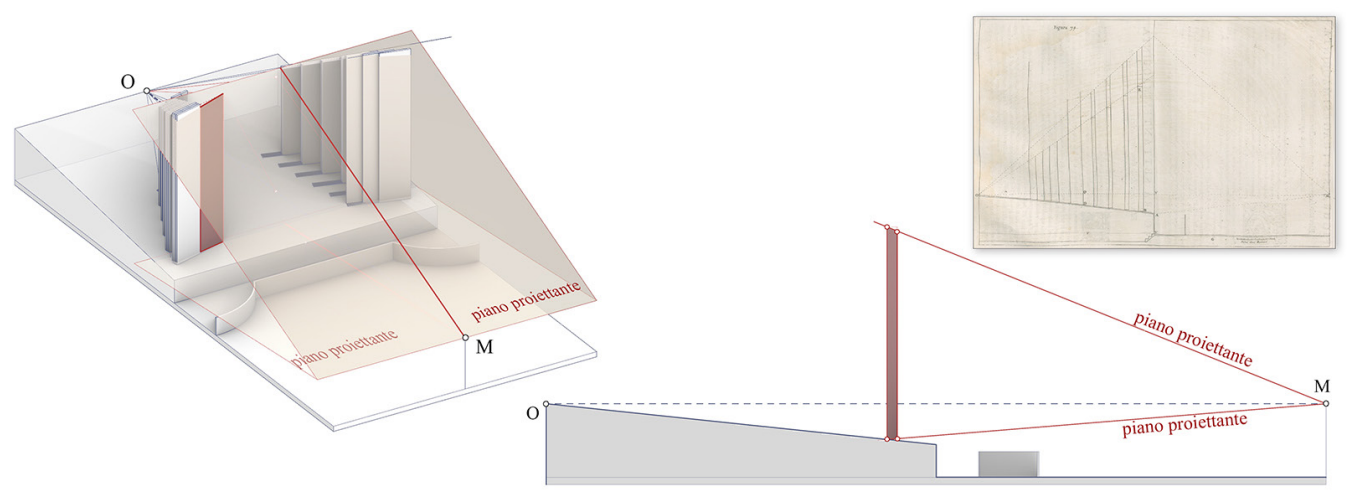


distanza', oggi centro di proiezione, è simmetrico del 'punto dell'occhio del teatro' rispetto al fronte della scena e viene a trovarsi in una posizione impossibile per lo spettatore, al centro delle scale di servizio ai palchi. Si tratta di una singolarità nella trattazione, che elude le ragioni della veduta vincolata sulla quale invece si fondano, in generale, tutte le applicazioni prospettiche di Pozzo [2]. II rilievo del piano del palco e dei canali è dunque il presupposto per il progetto della scena poiché, a questi rapporti, sono vincolati gli elementi fondamentali della prospettiva lineare che sarà dipinta sui diversi piani di quadro delle quinte.

Definita l'impostazione dell'edificio teatrale, Pozzo entra nel merito della costruzione delle prospettive sulle quinte e procede attraverso la loro rappresentazione in pianta e alzato. Se la pianta dei canali obliqui (figura 73 del primo libro) restituisce la posizione dei 'telari' delle scene, l'alzato (figura 74 del primo libro) ne consente il controllo dell'altezza. Per via dell'obliquità dei canali, le rette orizzontali in sommità di ogni 'telaro' appariranno oblique

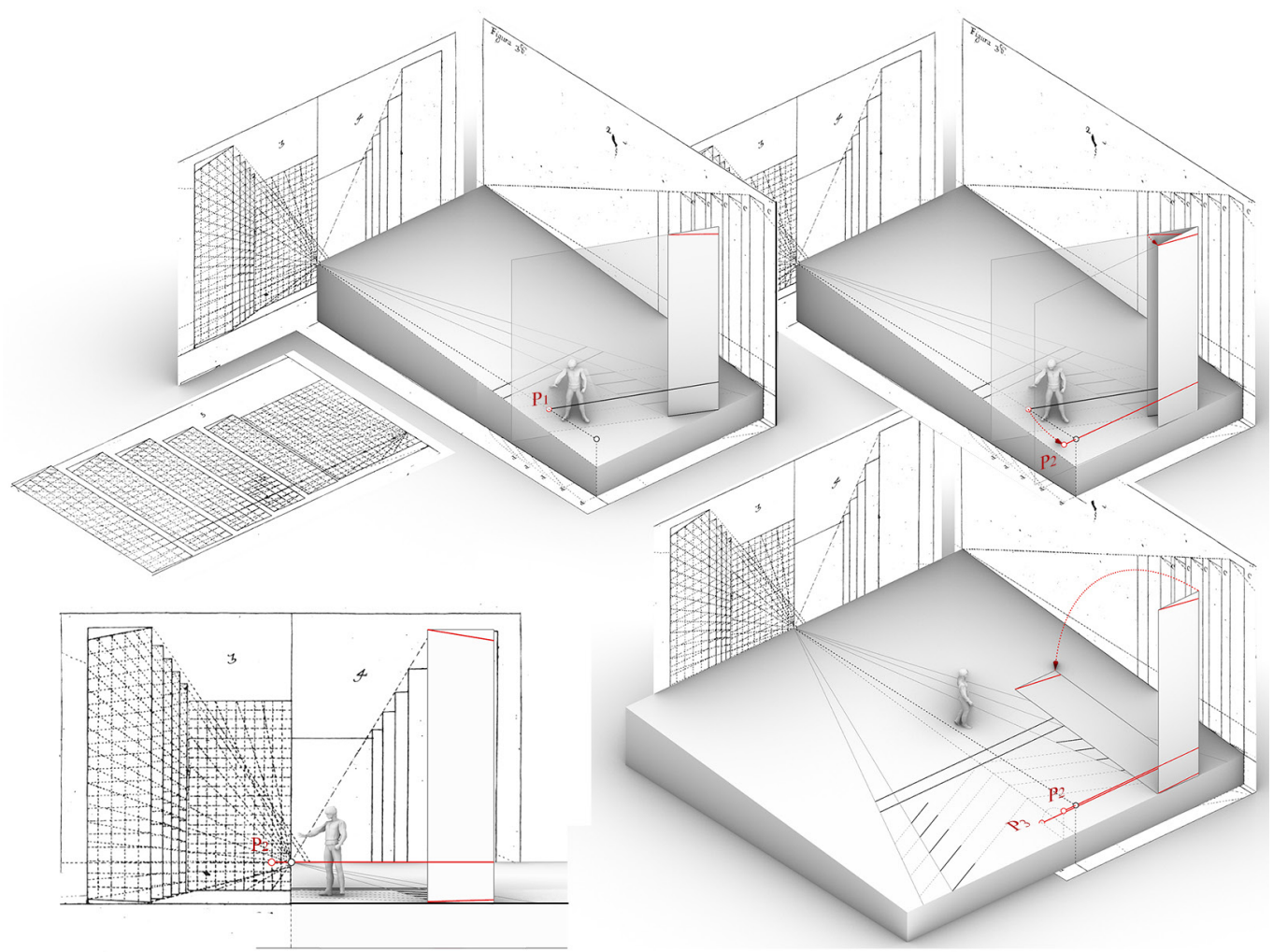

Fig. 5. Ricostruzione del procedimento impiegato per la costruzione della graticola sui 'telari' a partire dalla rotazione dei

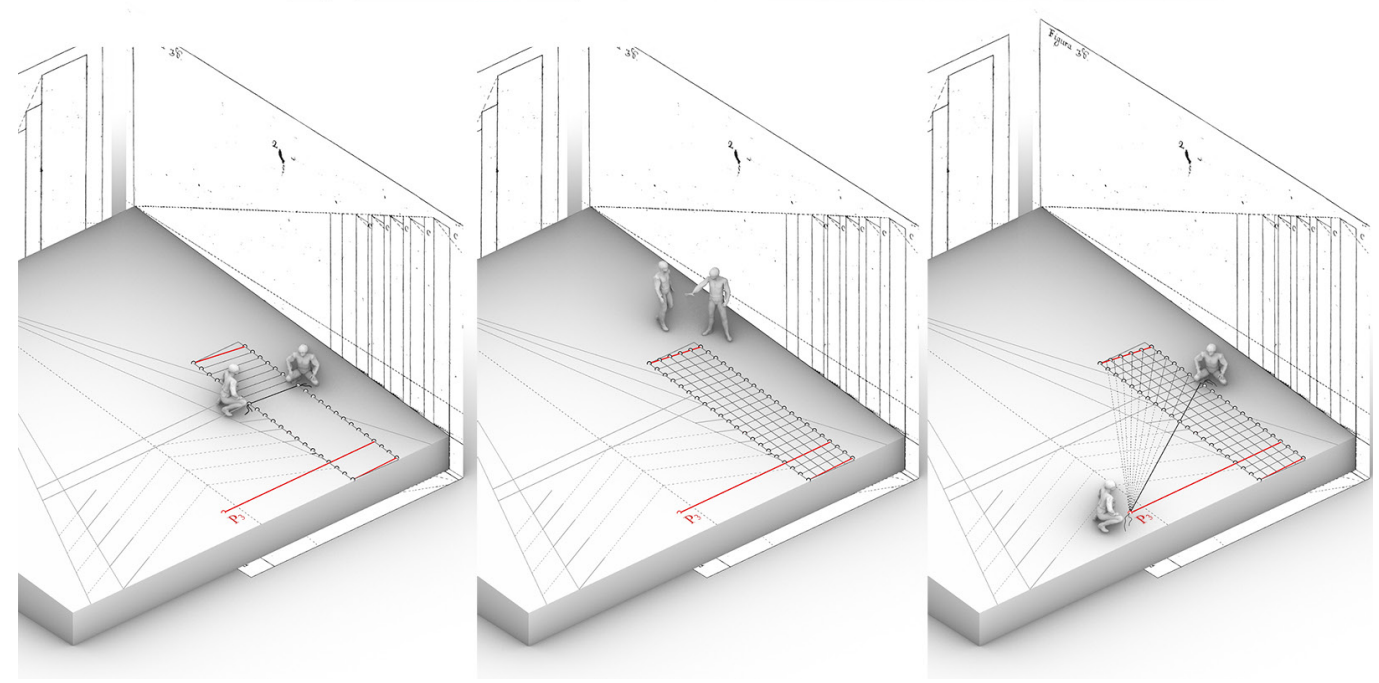


in prospettiva, come si vede chiaramente nella parte sinistra del disegno (S), vista prospettica della scena, collocato nella parte superiore della figura 75 del primo libro (fig. 2). Oggi diremmo che per rappresentarle bisogna costruire la fuga delle rette parallele al fronte della scena su un quadro accidentale (fig. 3), secondo un'idea lontana dalle pratiche in uso al tempo per la costruzione dei tracciati prospettici [Salvatore 2020, pp. 95- 108]. Così, per calcolare l'inclinazione della prospettiva di una retta che sarebbe dovuta apparire orizzontale agli occhi di un osservatore, Pozzo ricorre operativamente alla rappresentazione in sezione (figura $74 \mathrm{del}$ primo libro). Costruendo la retta proiettante le sommità dei 'telari' dal 'punto della distanza', ricava agevolmente le quote degli estremi dei segmenti cercati. In termini proiettivi Pozzo sta costruendo un piano che proietta classi di rette orizzontali, e che evidentemente intersecherà le quinte secondo rette inclinate le cui immagini appaiono orizzontali (fig. 4).

Fino a ora le costruzioni sono state eseguite in pianta e alzato su carta. Immaginiamo invece, da questo momento in poi, di trovarci sul piano del palco, e di dover dipingere le scene distese per terra, collocate in corrispondenza dei canali. Come nel caso dei teatri liturgici e delle quadrature, Pozzo ricorre alla graticolazione, predisposta su un bozzetto che sintetizza in un'unica prospettiva lineare l'intera scenografia, come se questa fosse realizzata sul piano del fronte della scena e poi ridotta in scala. Pozzo ha tutti gli elementi necessari per riprodurre la graticola della prima quinta, quella più grande, che giace sopra tutte le altre. Le rette verticali infatti si mantengono tali, mentre quelle che appaiono orizzontali, come quella in sommità della quinta si ricavano secondo il procedimento già indicato. Sarà dunque sufficiente dividere in parti uguali gli spigoli verticali opposti per ottenere una graticola in cui le rette orizzontali convergono correttamente verso il medesimo punto di fuga. Per misurare la degradazione della graticola sulla quinta successiva e per controllare la costruzione della prospettiva su tutte le quinte, Pozzo ha bisogno di determinare, per ognuna di esse, il punto di fuga delle rette perpendicolari al fronte della scena. Si tratta di uno dei passaggi di difficile interpretazione che giova analizzare attraverso un'analisi comparata del testo del primo volume e delle immagini del secondo.

Ognuno dei punti di fuga da determinare appartiene al piano della quinta a cui si riferisce e alla normale al fronte della scena condotta dal centro di proiezione. Per essere riverse in terra e disposte in corrispondenza dei canali, le quinte subiscono una rotazione intorno a un loro spigolo verticale per essere poi riverse sul piano del palco. Anche il punto di fuga delle normali al fronte della scena è interessato dalla stessa rotazione e si viene a trovare quindi nella metà

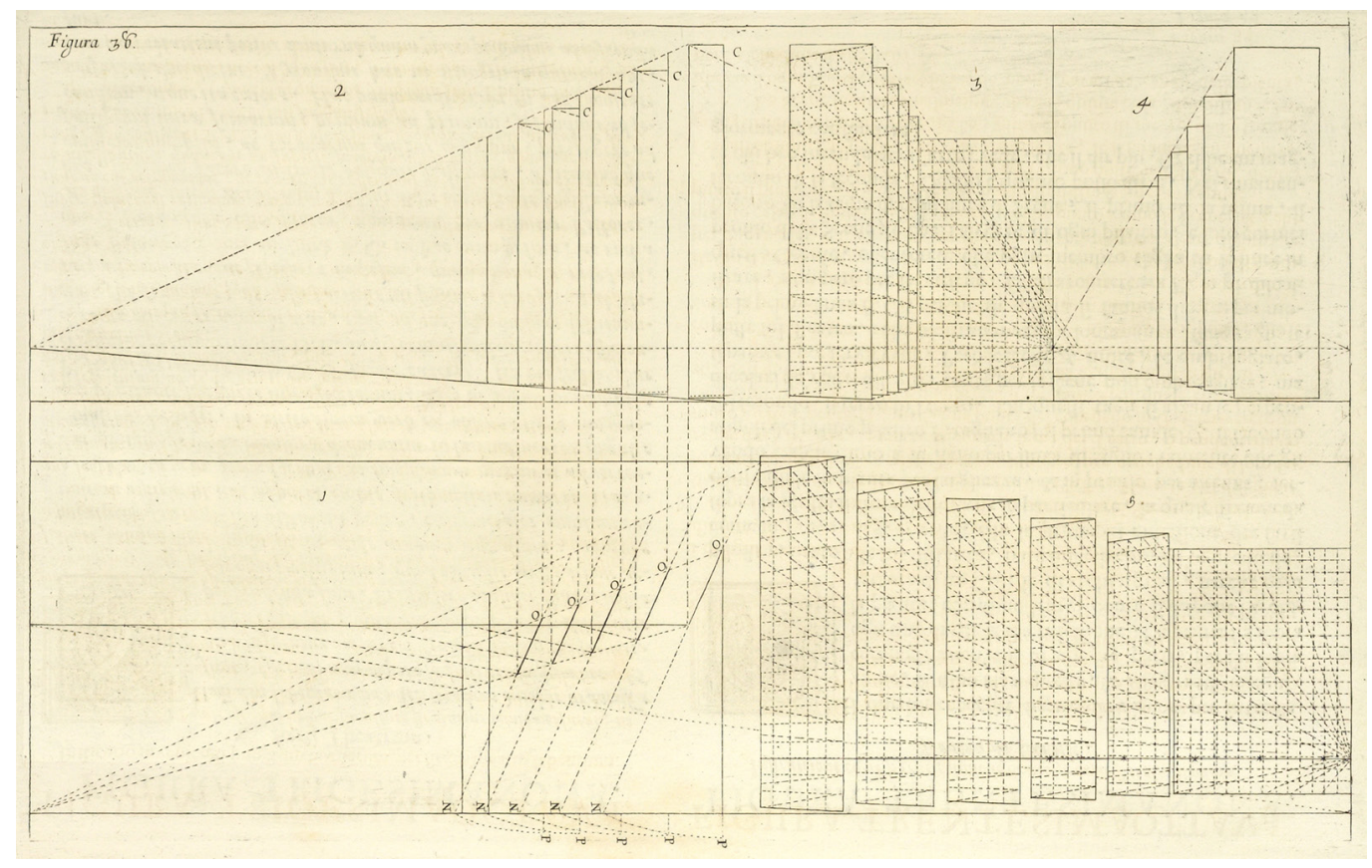


Fig. 7. Applicazione del metodo ad un soggetto architettonico secondo le figure 76 e 77 del primo
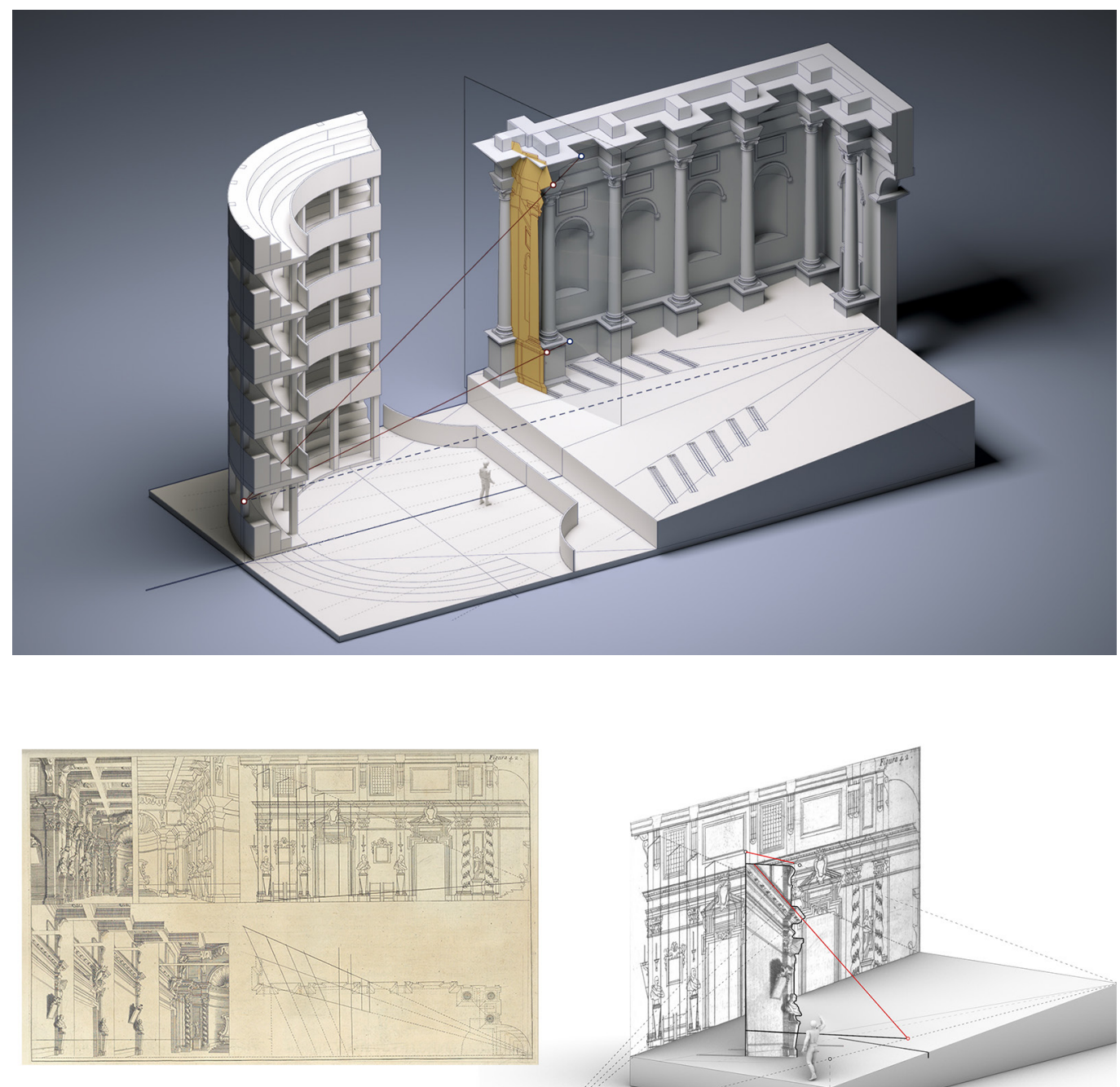

Fig. 8. Ricostruzione
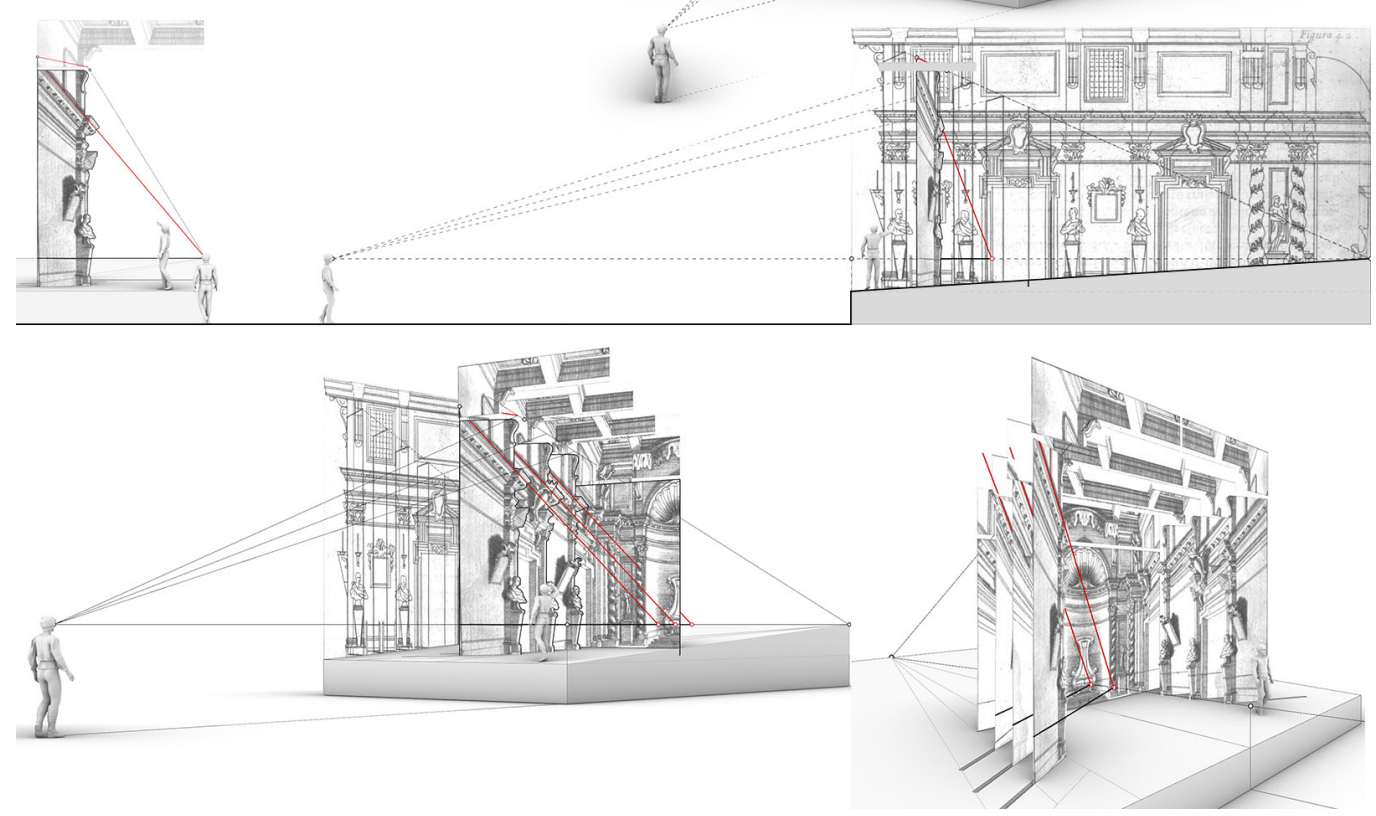
opposta del palco rispetto al punto principale della prospettiva della scena (fig. 5). Questa rotazione viene controllata da Pozzo in pianta e alzato, come mostrano i disegni della figura 75 del primo volume e il quadro di sintesi nella figura 38 del secondo (fig. 6). Ottenuta dunque da un secondo alzato (prospetto P collocato nella parte bassa della figura 75 del libro primo) la distanza lineare tra il punto principale e il suddetto punto di fuga ruotato, questa veniva riportata sul piano del palco. La graticolazione veniva dunque completata con la costruzione della prospettiva di questa classe di rette, attraverso una cordicella tinta di nero fissata nel punto di fuga appena costruito.

Le scene venivano quindi dipinte una dopo l'altra per essere successivamente inserite nei rispettivi canali [3]. II sistema triortogonale riprodotto nella graticolazione consentiva così, oltre alle usuali operazioni di trasporto della prospettiva dal bozzetto al 'telaro', l'esecuzione diretta di parte dei tracciati prospettici (fig. 7).

II secondo volume mostra una figura di sintesi commentata da un vero e proprio algoritmo numerato, inusuale rispetto al resto della trattazione, che riduce il procedimento a una sequenza operativa di passaggi, ognuno illustrato da uno dei disegni dell'incisione, che si concludono con la vera forma delle scene graticolate e separate le une dalle altre (figura 38 del secondo volume). Questa sintesi metodologica ricorre nei diversi modelli di scene che Pozzo propone a conclusione del secondo libro, a canali paralleli quanto obliqui, riferibili a diverse ambientazioni, fra cui il Teatro di Cortile, di Arsenale o di Anticamera (fig. 8). II repertorio dei disegni di cui si compongono questi modelli si compone della medesima sequenza: un bozzetto prospettico della scena nel suo insieme, una pianta, due alzati e le scene separate fra loro (fig. 9).

Fig. 9. Disegni dei teatr scenici nel secondo volume del 1700 .
Dall'alto verso il basso: Teatro di Cortile, il Teatro di Arsenale, il Teatro di Galleria, il Teatro di Anticamera, il Teatro di Tempio e il Coliseo.

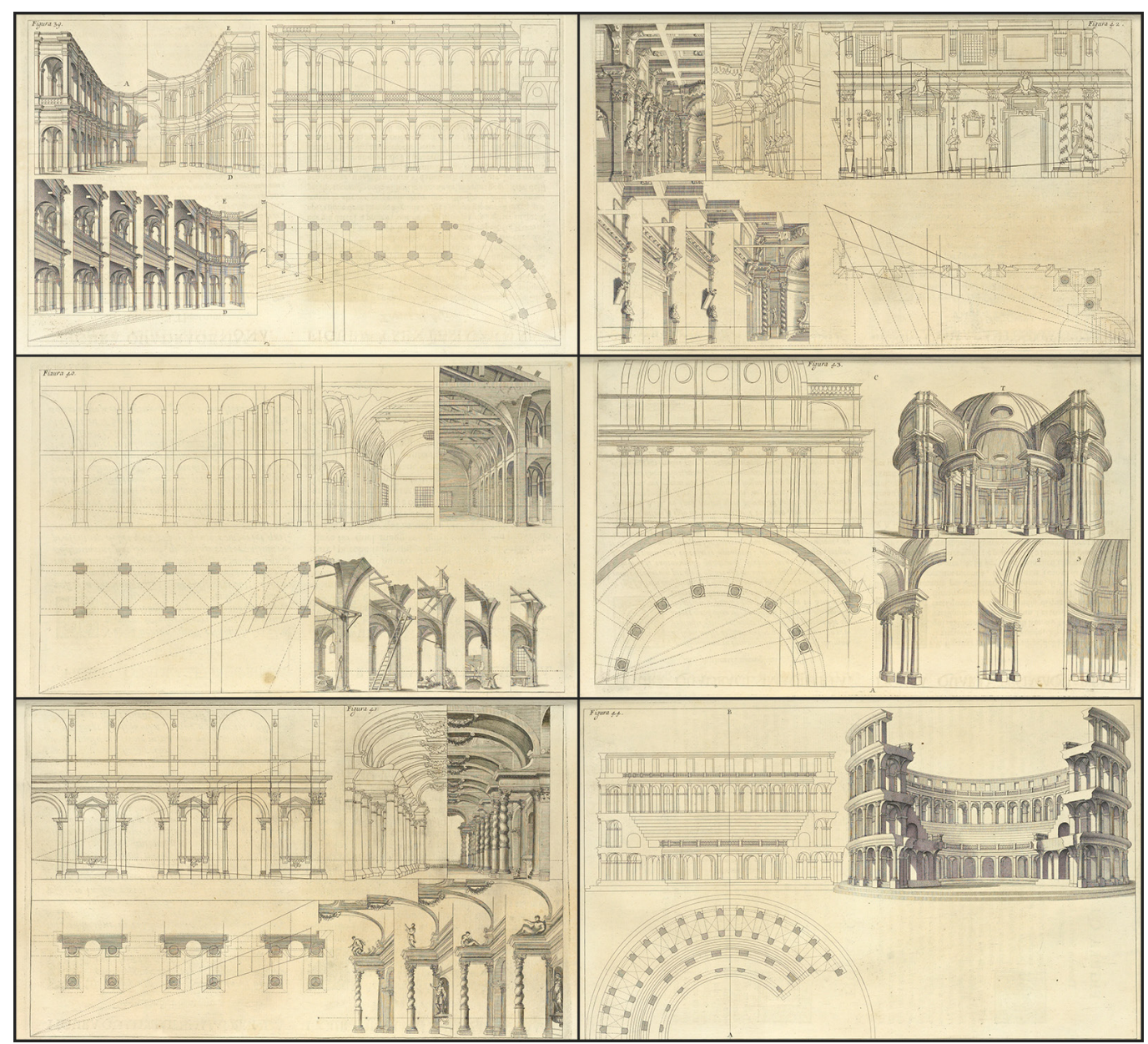




\title{
Conclusioni
}

Il modello di 'teatro scenico' descritto da Pozzo restituisce un'immagine del teatro barocco di fine secolo e dei procedimenti prospettici utilizzati per la progettazione e la realizzazione delle scene configurandosi, per questo, come una testimonianza tanto preziosa quanto rara. Da un punto di vista prospettico si tratta di uno degli approfondimenti più ricchi e articolati del trattato la cui interpretazione risulta particolarmente difficoltosa per via delle diverse condizioni di obliquità che introducono difficoltà interpretative tanto del testo quanto dei disegni e che si addizionano a ulteriori ambiguità dovute alla natura prospettica del soggetto stesso. II prospetto di una scena prospettica e perciò di una prospettiva solida, rappresenta infatti in vera forma le 'scene nude' ma restituisce allo stesso tempo in prospettiva l'immagine pittorica che vi è rappresentata, costringendo il lettore a una ginnastica visiva in cui si passa costantemente da una proiezione centrale a una parallela attraverso l'osservazione di uno stesso disegno e di disegni apparentemente affini. Questa palestra visiva sottolinea ancora una volta l'agilità con la quale Pozzo pratica la prospettiva, che si ravvisa anche nel sistema di graticolazione escogitato per il 'teatro scenico' che non si limita alle consuete operazioni di trasporto o ingrandimento, tipiche delle quadrature e delle Quarantore, ma che consente la costruzione diretta dei tracciati prospettici attraverso l'introduzione, sulla graticola, delle profondità.

II 'teatro scenico', in sintesi, spinge la pratica prospettica verso livelli di massima complessità che Pozzo affronta e risolve riversando nella prassi rigore metodologico e consapevolezza proiettiva, confermandosi, ancora una volta, maestro dell'arte dei linguaggi scenici.

\section{Note}

[I] Le scene a canali paralleli si risolvono con lo stesso metodo impiegato nel caso dei teatri liturgici.

[2] Di particolare interesse l'interpretazione di Ruffini, secondo cui la prospettiva nel teatro barocco non cerca l'isomorfismo fra lo spazio e la sua rappresentazione ma si configura invece come una metafora dello spazio [Ruffini 1972, pp. 221, 222].

[3] Le scene potevano essere dipinte in un luogo diverso dal teatro ma il procedimento sarebbe stato lo stesso.

\section{Riferimenti bibliografici}

Baglioni L. (2019). Progettare l'effimero. Analisi ed indagini sulle macchine delle Quarantore di Andrea Pozzo. In Belardi P. (a cura di). Riflessioni. L'arte del disegno, il disegno dell'arte.Atti del $41^{\circ}$ Convegno Internazionale dei docenti delle discipline della Rappresentazione, Perugia 19-2I settembre 2019, pp. 317-324. Roma: Gangemi Editore International.

Baglioni L., Salvatore M. (20 I 8). The Points of Concurrence Theory in Guidobaldo del Monte's Scenography. In diségno, n. 3, pp. 4I -52.

Horn A. (2019). Andrea Pozzo and the Jesuit "Theatres" of the Seventeenth Century. In Journal of Jesuit studies, n. 6, pp. 21 3-248.

Mancini F. (1966). Scenografia italiana. Milano: Fratelli Fabbri Editori.

Pascoli L. (1736). Vite de' pittori, scultori e architetti moderni. Roma: Antonio de' Rossi nella strada del Seminario Romano.

Povoledo E. (1979). Spazio scenico, prospettiva e azione drammatica nel teatro barocco italiano. In A. Schnapper (a cura di). La scenografia barocca, pp. 5- 17. Bologna: Clueb.

Pozzo A. (1 693). Prospettiva de' Pittori e architetti della Compagnia di Giesù. Parte prima. Roma: Stamperia di Giò.

Pozzo A. ( 1 700). Prospettiva de’ Pittori e architetti della Compagnia di Giesù. Parte seconda. Roma: Ex Thypographia Jo.

Ruffini F. (1972). Per una epistemiologia del teatro del '700: lo spazio scenico in Ferdinando Galli Bibiena. In G. Macchia (a cura di). II teatro italiano dall'umanesimo al Settecento, pp. 221-238. Roma: Istituto del teatro e dello spettacolo.

Salvatore M. (2020). Perspective Ingenuity. Methods andTools for the Construction of Applied Perspective. In diségno, n. 6, pp. 95 - I 08.

\author{
Autori \\ Leonardo Baglioni, Sapienza Università di Roma, leonardo.baglioni@uniromal.it \\ Marta Salvatore, Sapienza Università di Roma, marta.salvatore@uniromal.it
}

Per citare questo capitolo: Baglioni Leonardo, Salvatore Marta (2021). Andrea Pozzo e l'arte dei linguaggi scenici/Andrea Pozzo and the art of scenic languages. In Arena A., Arena M., Mediati D., Raffa P. (a cura di). Connettere. Un disegno per annodare e tessere. Linguaggi Distanze Tecnologie. Atti del $42^{\circ}$ Convegno Internazionale dei Docenti delle Discipline della Rappresentazione/Connecting. Drawing for weaving relationship. Languages Distances Technologies. Proceedings of the $42^{\text {th }}$ International Conference of Representation Disciplines Teachers. Milano: FrancoAngeli, pp. $179-196$. 


\title{
Andrea Pozzo and the Art of Scenic Languages
}

\author{
Leonardo Baglioni \\ Marta Salvatore
}

Abstract

The contribution investigates the forms of scenographic representation in Pozzo's work, with particular reference to theatrical scenography. Founding pedagogical principle within the Society of Jesus, the baroque Jesuit theater became an instrument of persuasion and a vehicle for the collective sharing of Christianity's messages, acquiring a central role in education. Therefore, theatrical scenography is in ideological continuity with the pedagogical objectives at the basis of the scenography idea that animates all Pozzo's work that is also reflected in the practice of perspective. In those years, the Jesuit theater differs in terms of content from the entertainment theatre but shares with it structure, machinery and scenic apparatus. Pozzo's activity as a theatrical scenographer is little known, nevertheless his contribution appears fundamental, from perspective point of view, in the evolution history of the scenic space because it testifies the practice of scenography in years when the baroque theater achieved its mature configuration. Moreover, in Pozzo's treatise, the scenic theater differs from the other works because it presents a series of procedural criticalities introduced by the obliquity of the telari (wings), wisely resolved by Pozzo with projective knowledge and methodological rigor.

Keywords

Andrea Pozzo, scenography, theater, perspective, net-work on frames.

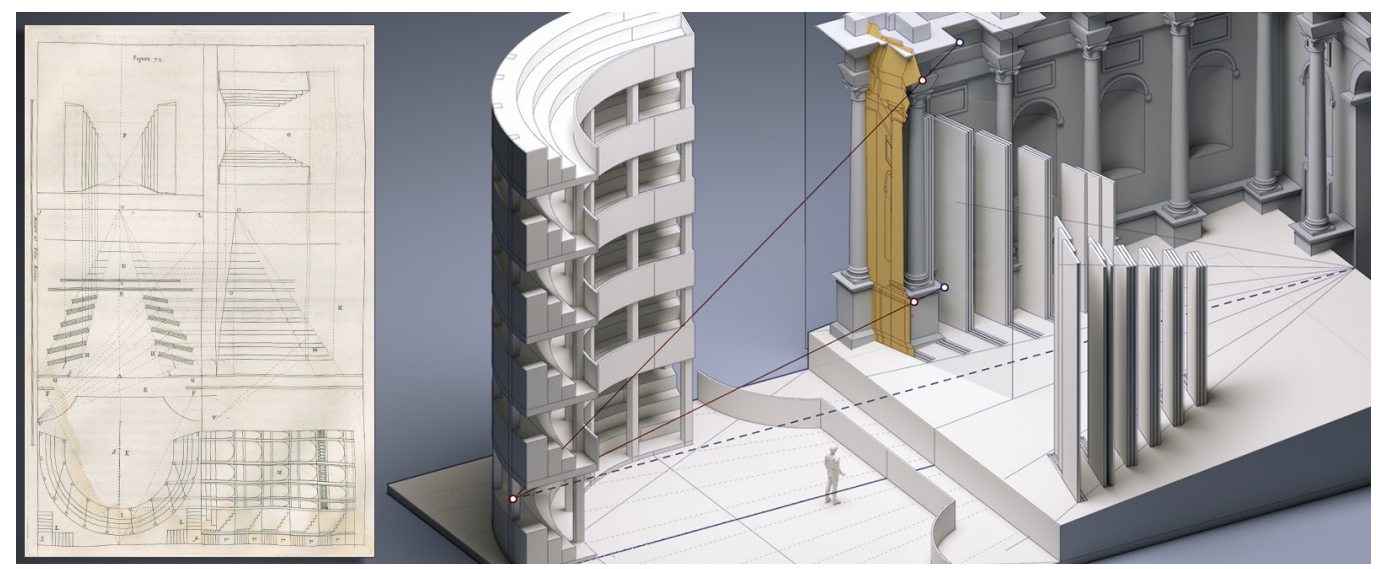




\section{Scenic languages and theatrical scenography}

In Perspectiva pictorum et architectorum published in two volumes in 1693 and 1700, Pozzo pours out memories of his realized works, describing them in distinctly operative terms according to the manualistic manner in use at the time. The two volumes of the treatise teach the reader, not necessarily versed in the topic, to construct perspective to employ in the realization of remarkable applications, as widely testified by his work. Graphic models of applied perspectives find place in the general context of a printed treatise that reflects its own artistic production. These models are related to the architectural perspectives (vertical or 'from below') and to the perspectives painted on the telari that compose liturgical theaters, realized for the religious celebrations of Quarantore. The idea of scenography generally affects Pozzo's figurative art which developed in the performance and exhibition culture of Seventeenth Century. In fact, his architectural perspectives are scenographic perspectives, as well as the telari that compose the scenes of the liturgical theaters [Baglioni 2019, pp. 317-324]. This transversal idea of scenography, understood in its broadest perspectival meaning, is also confirmed from a strictly projective point of view. In fact, many of Pozzo's works are compositions of perspectives able to recreate the illusion if simultaneously observed from the correct point of view, according to the aggregation of linear perspectives realized on differently oriented picture planes. This model is typical in the theatrical scenery since its first Renaissance configurations [Baglioni, Salvatore 2018, pp. 41-52]. However, the relationships between architectural perspectives, liturgical theater, and stage theater are rooted in the pedagogical and educational aim that animates the Jesuit pictorial production of those years. This purpose finds in the synergistic action of performance and visual rhetoric, a tool for persuasion and formative action of young and faithful [Horn 2019, pp. 216-217]. Jesuit theater, not only practiced in colleges and seminaries, presented itself as a pedagogical alternative to the laical Baroque spectacle very popular at the time, distancing itself in terms of content but sharing with it structure, machinery and apparatus.

We do not have detailed information about Pozzo's activity as a theatrical scenographer. We know that he was active in Milan and Venice [Horn 2019, p. 22I] and that, according to Pascoli's account, during his time in Rome he made three changes of scenes for the Seminario Romano theater [Pascoli 1736, p. 264].

However, the pages of the treatise dedicated to scenic theater testify the full awareness of an operative praxis that was consolidating throughout the $17^{\text {th }}$ century and that con-
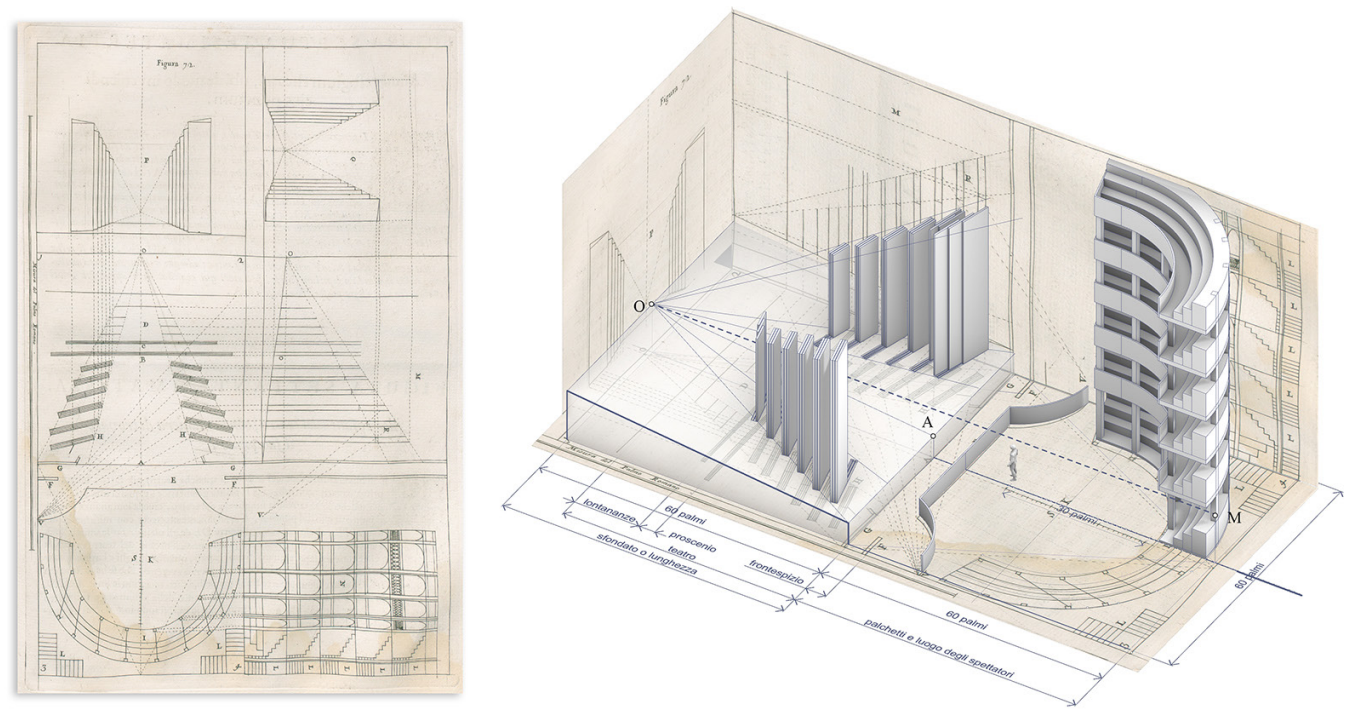
stitute a particularly precious testimony, in terms of consistency and temporal collocation. In fact, Pozzo's contribution is the expression of a mature configuration of the scenic structure of the Baroque theater, which in those years would have been radically changed by the Bibiena introduction of the accidental perspective model.

\section{Perspective practice in the art of scenography construction}

In the commentary on the figure 72 of the volume of 1693 , Pozzo introduce the theme of the 'scenes for the stages', in perfect continuity with the previously illustrated construction of liturgical theaters. From a perspective and constructive point of view, these theatres make use of similar scenographic apparatus, both composed of a set of linear perspectives seen from the same projection centre and painted on separate telari. While liturgical theatres, mostly static, were generally located in churches in place of the altars and in continuity with the existing architecture, the 'scenes for the stages' are configured, in those years, as independent buildings capable of hosting dynamic scenes that are renewed several times and that respond to the spatial and predetermined configuration of the theatre building. The complexity inherent in the changeability of the scenic apparatus, in relation to the constraints given by the hosting theatre building, are the main elements that differentiate 'scenic theatre' from 'liturgical theatre'.

The Baroque scenography is dynamic and during the same performance there are many scene transformations to be performed [Mancini 1966, p. 49]. Thus, the telari that carry the scenes are inserted in 'grooves' (slits made on the stage floor) capable of holding more than one and sliding them on each other to respond more quickly and efficiently to the sudden changes of the scene [Povoledo 1979, pp. I0, I I]. In the scenographic practice of the time, the grooves were generally parallel to the front of the stage or parallel to each other but oblique with respect to the front, according to a model in use in Italian theatre to which Pozzo explicitly refers. The arrangement of the 'grooves' had a decisive influence on the perspective structure of the scene, especially if they were oblique. This had to be considered

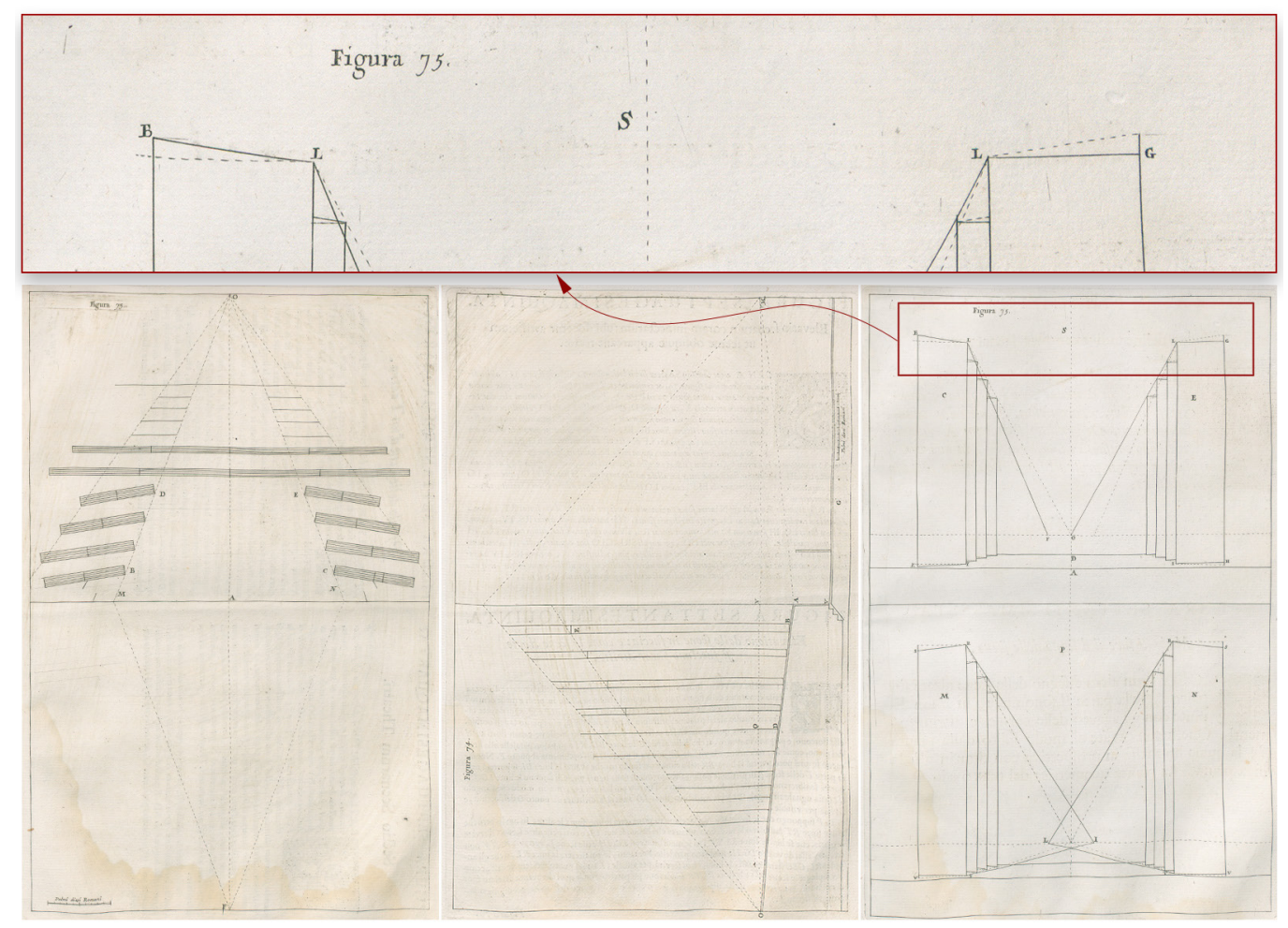


Fig. 3. Identification of the vanishing point of the straight lines parallel to the front of the scene according to a projective approach. Above left the quadrilateral true form of the first wing of the scene.

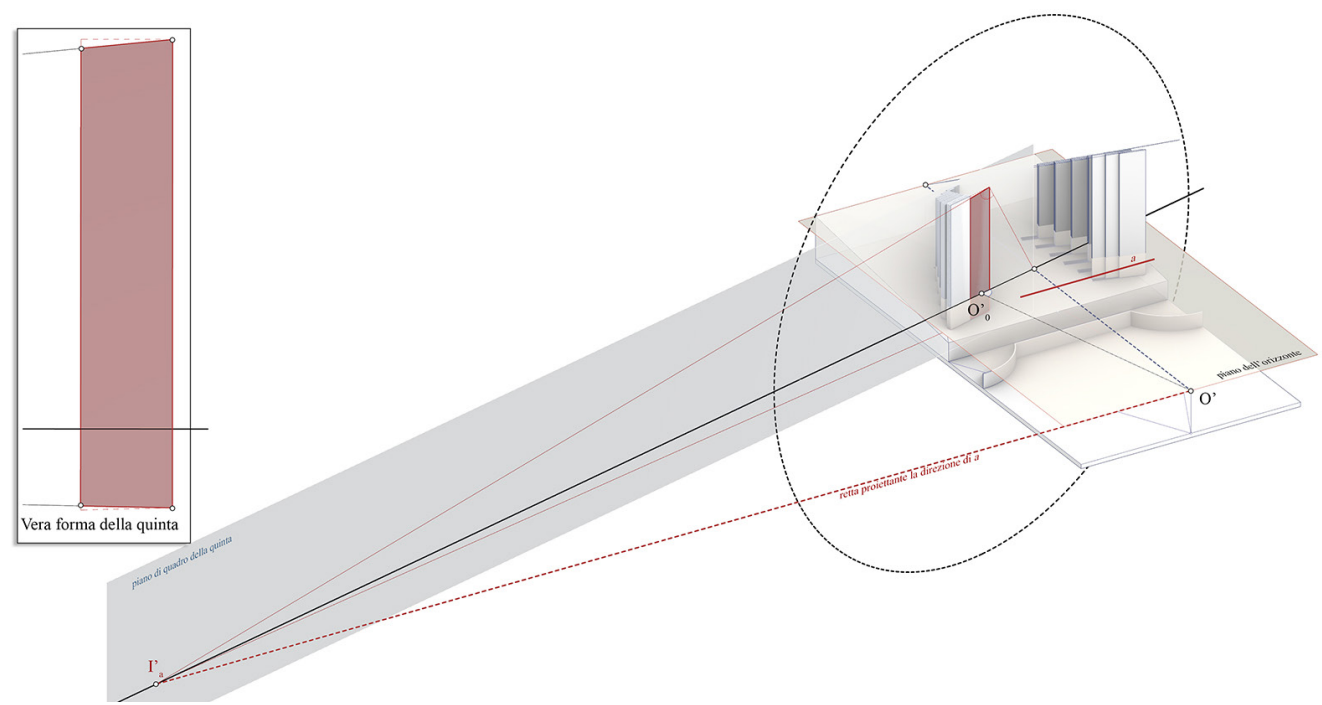

when designing the theatre building or when designing the stage in the case of already built theatres. In both volumes of the treatise, Pozzo considers both parallel and oblique 'grooves', but it is the latter that dictate conditions that bind the perspective system as a whole and the most consistent part of the treaty is dedicated to this arrangement [I].The operative and experimental approach that permeates Pozzo's work is revealed with extreme vigour in the pages dedicated to the scenic apparatus. Unlike other propositions characterised by exactness and methodological precision, the 'scenes for the stages' present many passages difficult to interpret and some graphic inconsistencies. Therefore, the critical interpretation analysis that follows, results from the integration of the philological reading of the text and its graphic apparatus with the perspective practices in use at the time.

In order to fully understand the meaning of the above-described procedures, one is forced to put himself in the shoes of the person who would actually have to paint the perspectives of the scenes, inside the theatre, lying on the plane of the floor, where the construction necessarily had to satisfy the rigour and rigidity characteristic of Pozzo's perspective production. In the first book, the treatise begins with a careful description of the elements of which the theatre building is composed and its ideal dimensions. The so-called 'point of the theater', i.e. the vanishing point of the edges of the contracted scenic box orthogonal to the front of the scene, is considered part of the building (fig. I). In a scenography with oblique grooves the position of this point is fixed and results from the intersection of the visual lines that lie on the inclined plane of the floor and that touch the channels towards the inner part of the scene. The 'point of distance', today named centre of projection, is symmetrical to the 'point of the theatre' with respect to the front of the stage and is located in an impossible position

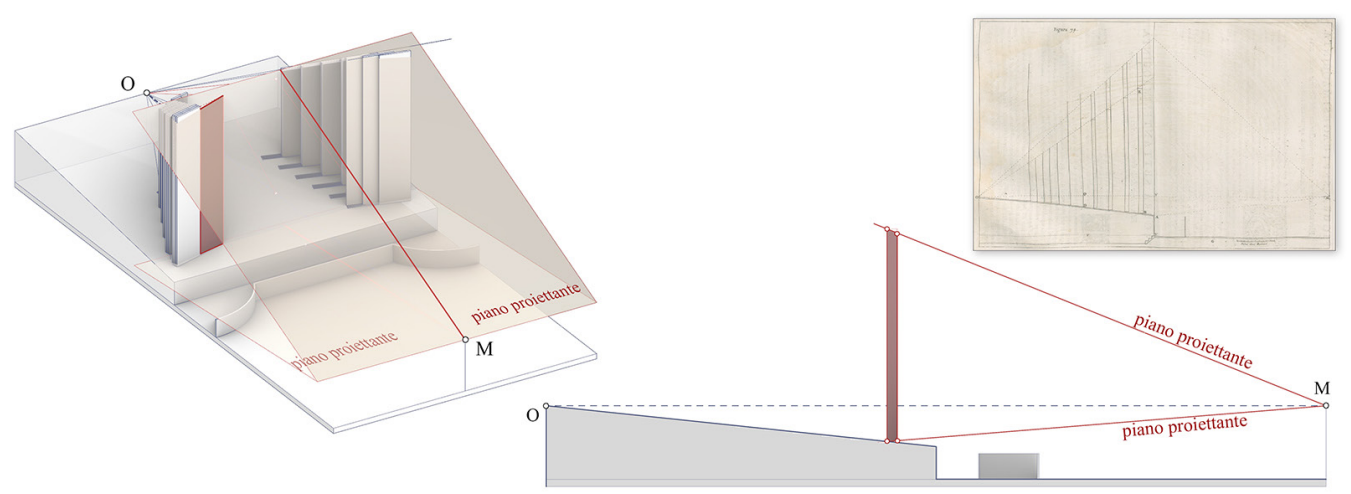


for the spectator, in the centre of the service stairs to the theatre's dais. This is a singularity in the treatise, which eludes the reasons for the restricted sight on which, in general, all Pozzo's perspective applications are based [2]. The survey of the stage floor and of the grooves is therefore the prerequisite for the project of the scene, because the position of the canals constrains the fundamental elements of the linear perspective that will be painted on the different picture planes of the wings.

After defining the layout of the theatre building, Pozzo enters into the construction of the perspectives on the wings and proceeds through their representation in plan and elevation method. If the plan of the oblique 'grooves' (figure 73 of the first book) defines the position of the telari (frames) of the scene, the elevation (figure 74 of the first book) allows the control of the height. Because of the obliquity of the channels, the horizontal lines at the top of each telaro will appear oblique in perspective, as is clearly seen in the left part of the
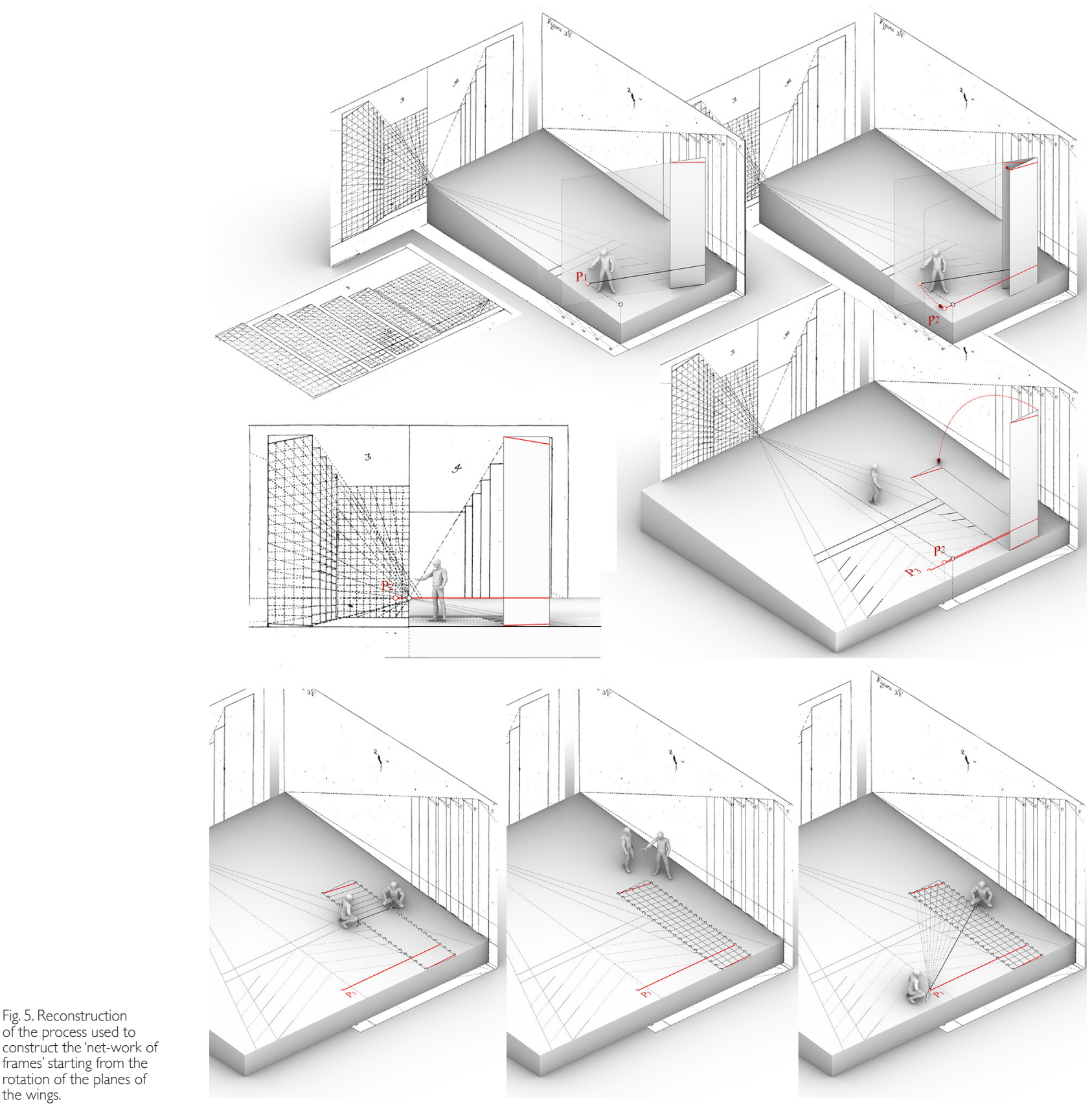
drawing (S) -perspective view of the scene- located in the upper part of figure 75 of the first book (fig. 2). Today we would say that to represent them it is necessary to construct the vanishing point of the lines parallel to the front of the scene on an accidental frame (fig. 3 ), according to an idea distant from the practices in use at the time for the construction of perspective traces [Salvatore 2020, pp. 95- 108]. Thus, in order to calculate the inclination of the perspective of a straight line that should have appeared horizontal to the eyes of an observer, Pozzo uses section representation (fig. 74 of the first book). He easily obtains the heights of the extremes of the segments sought constructing the line that projects the tops of the canvases from the point of distance. In projective terms Pozzo is constructing a plane that projects classes of horizontal lines which evidently intersect the wings according to inclined lines whose images appear horizontal (fig. 4).

Until now the constructions have been carried out in plan and elevation on paper. From now on, let us imagine to be on the stage floor, and to have to paint the scenes lying on the ground, placed in correspondence with the canals. Like in the case of liturgical theatres and Quarantore, Pozzo makes 'net-work on frames" (or 'squares'), prepared on a sketch that synthesises the entire scenography in a single linear perspective, as if it were created on the plane of the front of the stage and then reduced in scale. Pozzo has all the necessary elements to reproduce the 'net-work' of the first wing, the largest one, which lies above all the others. In fact, the vertical lines are maintained, while those that appear horizontal, such as the one at the top of the wing, are obtained according to the procedure already indicated. It will therefore be sufficient to divide the opposite vertical edges into equal parts to obtain a 'net-work' in which the horizontal lines correctly converge towards the same vanishing point. To measure the degradation of the 'net-work' on the following wing and to control the construction of the perspective on all the wings, Pozzo needs to determine, for each of them, the vanishing point of the straight lines perpendicular to the front of the scene. This is one of the most difficult passages to interpret, and it is useful to examine it through a comparative analysis between the text of the first volume and the images of the second. Each of the vanishing points to be determined belongs to the plane of the wings to which it refers and to the line perpendicular to the front of the stage, conducted by the projection centre. In order to be placed on the ground and arranged in correspondence with the channels, the wings undergo a rotation around one of their vertical edges and then are placed on the stage plane. The vanishing point of the lines perpendicular to the front of the

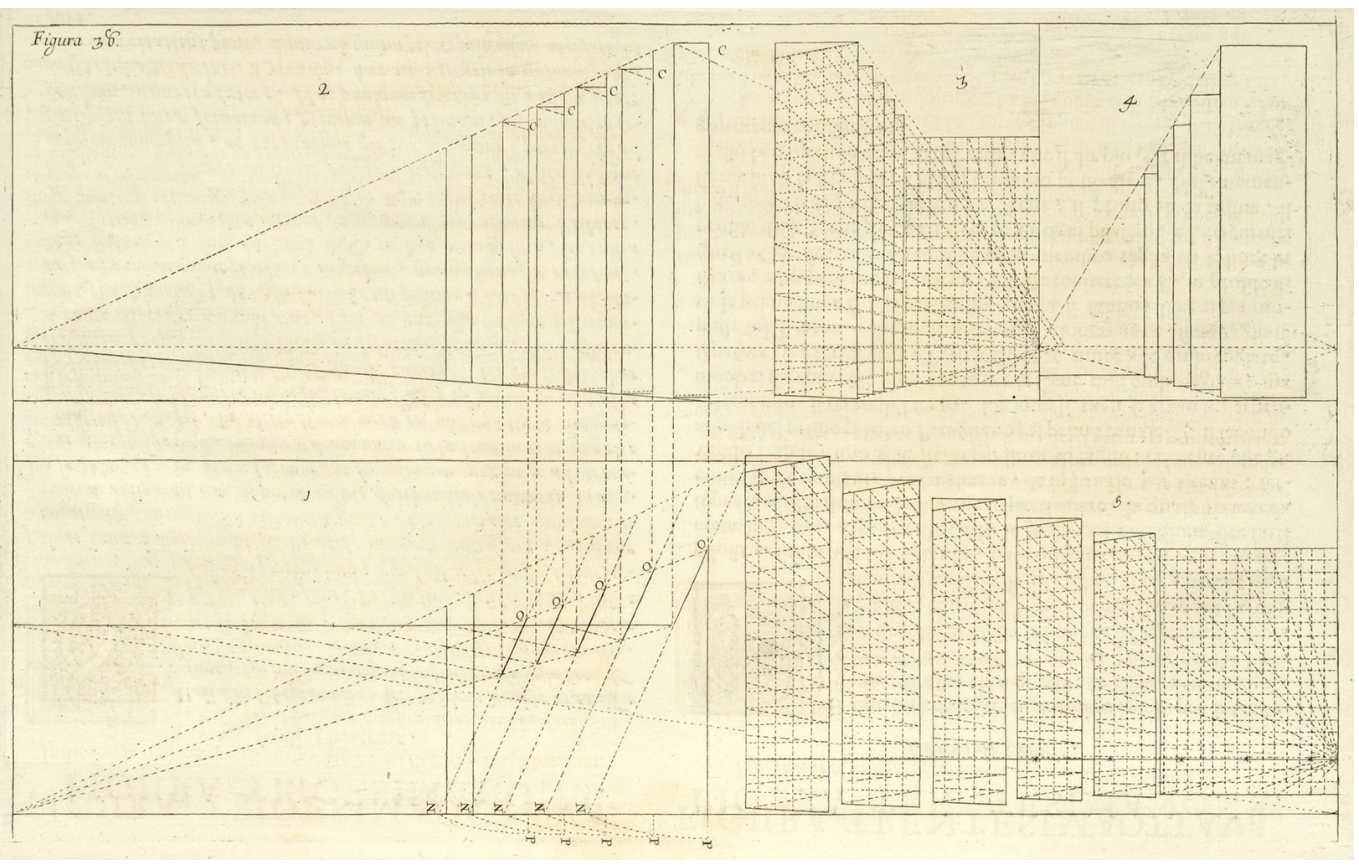


Fig. 7. Application of the method to an architectural subject according to figures 76 and 77 of the first book
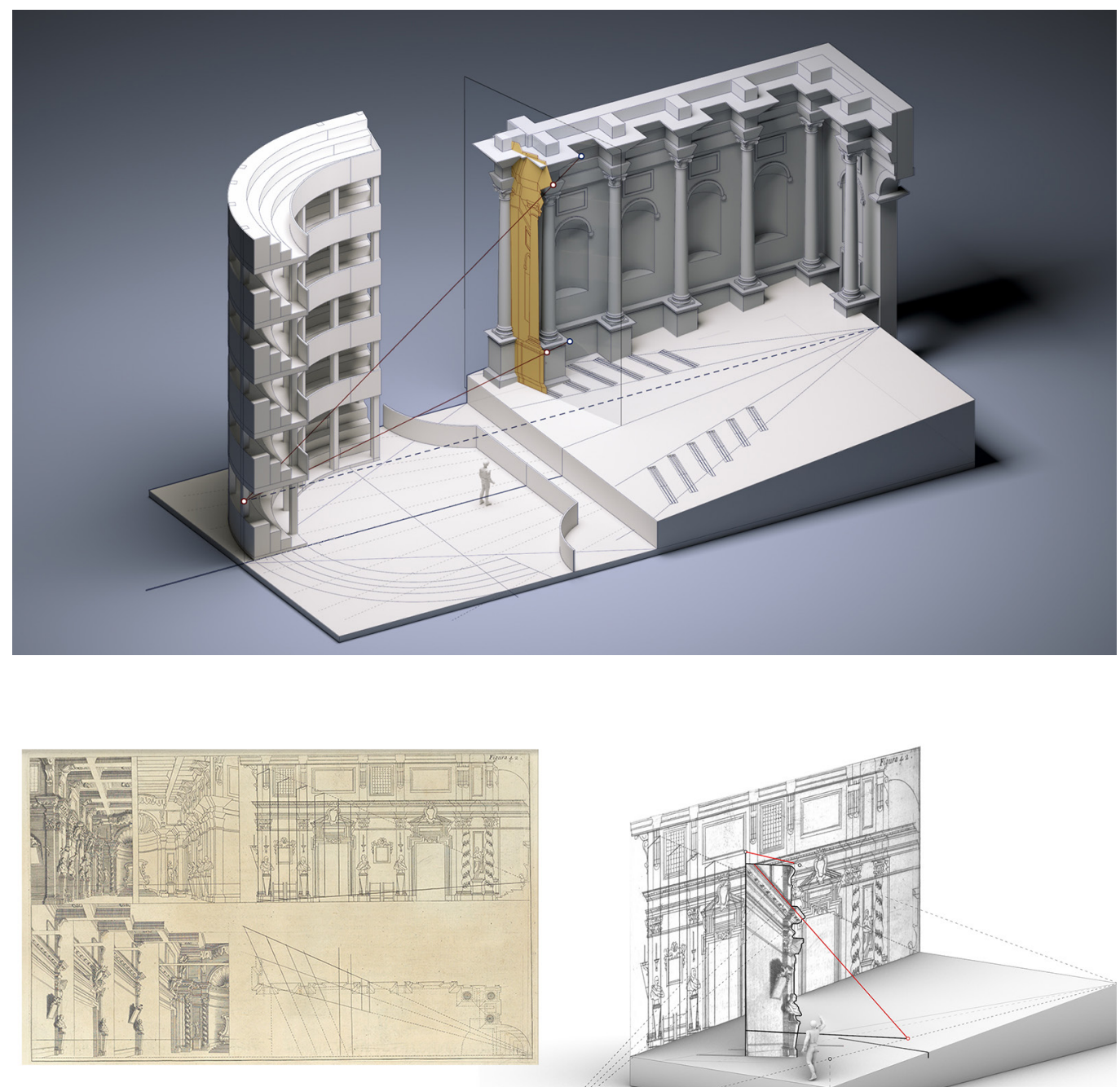

Fig. 8. Reconstruction of the scenes in the AntichamberTheatre represented in figure 42
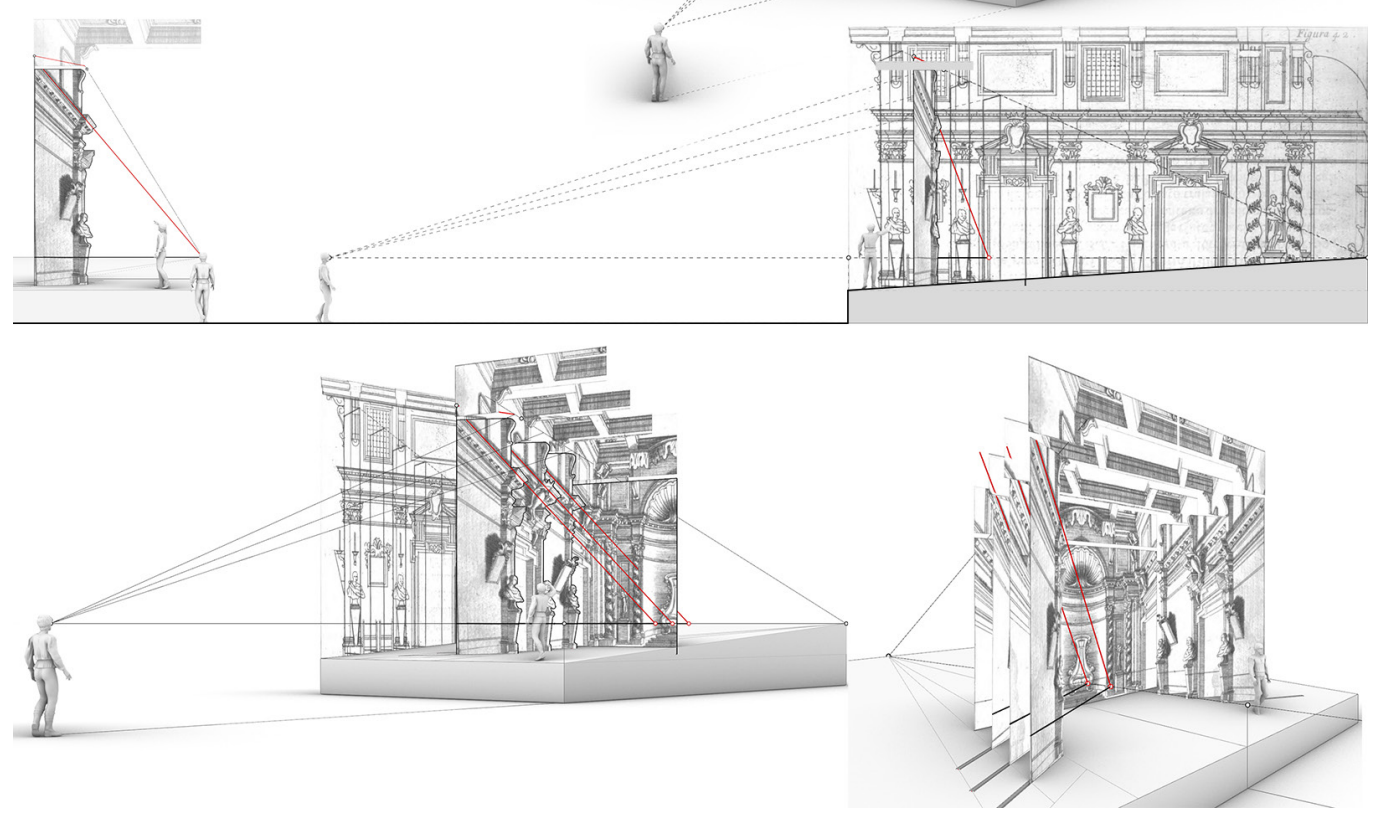
stage is also affected by the same rotation and is therefore located in the opposite half of the stage with respect to the principal point of the perspective of the scene (fig. 5). This rotation is controlled by Pozzo in plan and elevation, as shown in the drawings in figure 75 of the first volume and in the synthesis in figure 38 of the second (fig. 6). Once the linear distance between the principal point and the aforementioned rotated vanishing point had been obtained, using a second elevation (elevation P located in the lower part of figure 75 of the first book), it was transferred to the plane of the stage. In this way, the 'net-work' was completed with the construction of the perspective of this class of lines, through a black-dyed rope fixed to the newly constructed vanishing point.

The scenes were painted one after the other and then inserted into their respective grooves [3]. The triorthogonal system reproduced in the graticulation thus allowed the direct execution of part of the perspective traces (fig. 7) in addition to the usual operations of transporting the perspective from the sketch to the canvas.

The second volume shows a synthesis figure commented by an actual numbered algorithm, unusual with respect to the rest of the treatise, which reduces the procedure to an operative sequence of steps. All steps are illustrated by one of the drawings of the engraving and conclude with the true form of the "Net-works on Frames" separated one from the other (figure 38 of the second volume). This methodological synthesis recurs in the different models of the scenes that Pozzo proposes at the end of the second book, with parallel and oblique grooves, referring to different settings, including the Courtyard, Arsenal or Antichamber Theatre (fig. 8). The repertoire of drawings that compose these models consists of the same sequence: a perspective drawing of the scene as a whole, a plan, two elevations and the "Net-works on Frames" separated from each other (fig. 9).

Fig. 9. Drawings of the scenic theatres in the second volume of the 1700 s. From top to bottom: the Court Theatre, the Arsenal Theatre, the Gallery Theatre, the Antichamber Theatre, the Temple Theatre and the Coliseum.

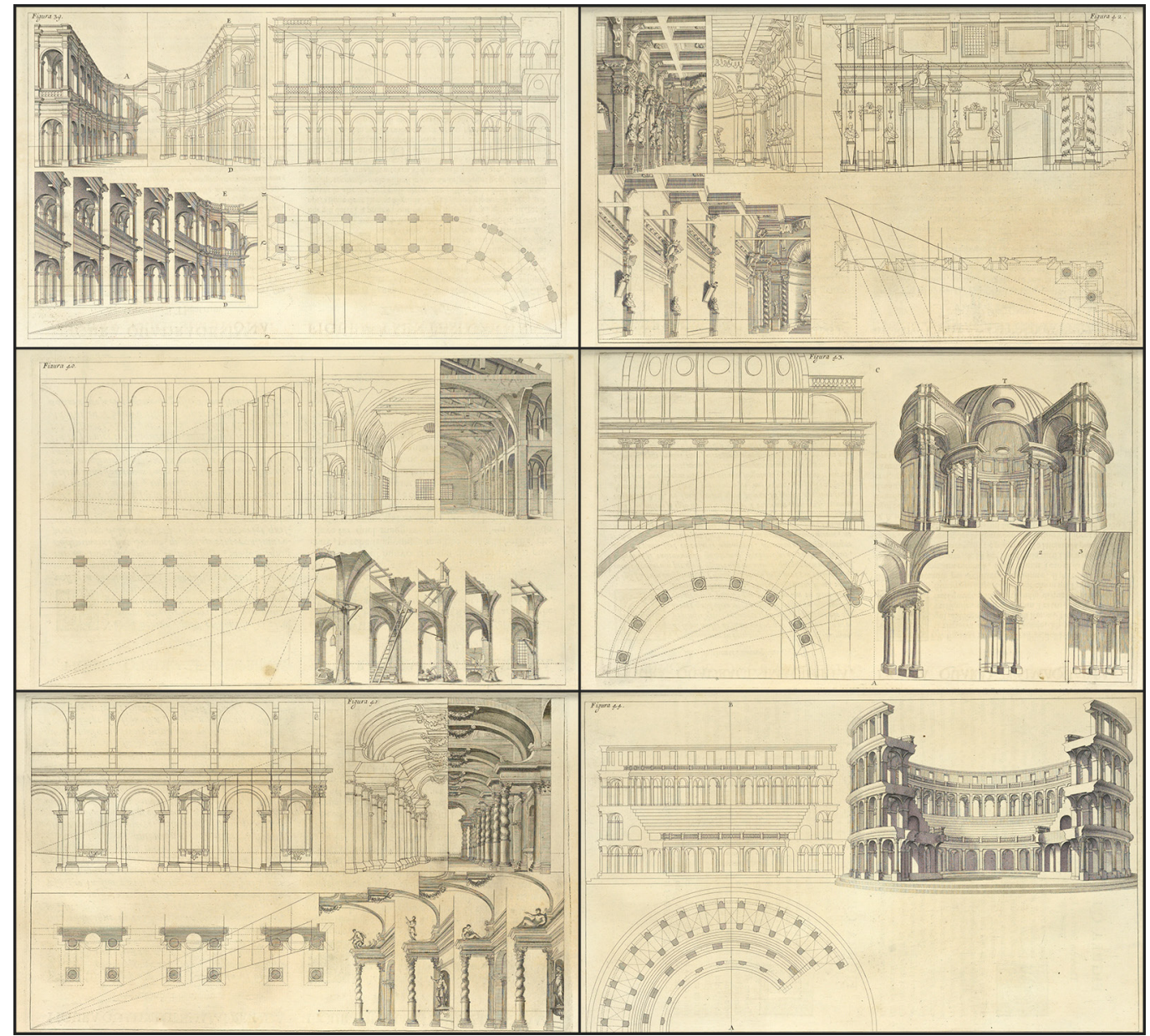




\section{Conclusions}

The model of the scenic theater described by Pozzo gives an image of the baroque theater of the end of the century and describes the perspective procedures used for the design and the construction of scenes, configuring itself as a precious and rare testimony. From a perspective point of view, this is one of the richest and most articulated sections of the treatise. Its interpretation is particularly complex because of the different conditions of obliquity that introduce interpretative difficulties both in the text and in the drawings, in addition to ambiguities due to the perspective nature of the subject. In fact, the elevation of a perspective scene, and therefore of a solid perspective, represents in true form the scene nude but at the same time provides the perspective image that is there represented, forcing the reader to visual gymnastics where he constantly passes from a central projection to a parallel one through the observation of the same and apparently affine drawings. This visual gymnasium once again underlines the agility with which Pozzo practices perspective, which is also evident in the system of 'net-works' devised for the scenic theater. In fact, this operation is not limited to the usual procedures of drawing transferring or scaling, typically used for the architectural and Quarantore perspectives, but allows the direct construction of the perspective traces through the introduction of the depths on the 'net-work'.

In synthesis, the scenic theater moves the practice of perspective towards maximum levels of complexity that Pozzo faces and resolves by pouring methodological rigor and projective awareness into his practice, once again confirming himself, as a master of the art of the scenic languages.

\section{Notes}

[I] Scenes with parallel grooves are resolved by the same method employed in the case of liturgical theaters.

[2] Ruffini's interpretation is particularly interesting; according to his thesis, in Baroque theater perspective does not pursue the isomorphism between the space and its representation but is instead configured as a metaphor of the space [Ruffini 1972 , pp. 221, 222].

[3] The scenes could be painted in a different place than the theater, but the process would be the same.

\section{References}

Baglioni L. (2019). Progettare l'effimero. Analisi ed indagini sulle macchine delle Quarantore di Andrea Pozzo. In Belardi P. (a cura di). Riflessioni. L'arte del disegno, il disegno dell'arte. Atti del $41^{\circ}$ Convegno Internazionale dei docenti delle discipline della Rappresentazione, Perugia 19-2I settembre 2019, pp. 317-324. Roma: Gangemi Editore International.

Baglioni L., Salvatore M. (20 I 8). The Points of Concurrence Theory in Guidobaldo del Monte's Scenography. In diségno, n. 3, pp. 4I -52.

Horn A. (2019). Andrea Pozzo and the Jesuit “Theatres" of the Seventeenth Century. In Journal of Jesuit studies, n. 6, pp. 2 I 3-248.

Mancini F. (1966). Scenografia italiana. Milano: Fratelli Fabbri Editori.

Pascoli L. ( 1736). Vite de' pittori, scultori e architetti moderni. Roma: Antonio de' Rossi nella strada del Seminario Romano.

Povoledo E. (1979). Spazio scenico, prospettiva e azione drammatica nel teatro barocco italiano. In A. Schnapper (a cura di). La scenografia barocca, pp. 5- 17. Bologna: Clueb.

Pozzo A. ( 1693$)$. Prospettiva de’ Pittori e architetti della Compagnia di Giesù. Parte prima. Roma: Stamperia di Giò.

Pozzo A. ( 1700). Prospettiva de' Pittori e architetti della Compagnia di Giesù. Parte seconda. Roma: Ex Thypographia Jo.

Ruffini F. (1972). Per una epistemiologia del teatro del '700: lo spazio scenico in Ferdinando Galli Bibiena. In G. Macchia (a cura di). II teatro italiano dall'umanesimo al Settecento, pp. 221-238. Roma: Istituto del teatro e dello spettacolo.

Salvatore M. (2020). Perspective Ingenuity. Methods and Tools for the Construction of Applied Perspective. In diségno, n. 6, pp. 95 - I08.

\footnotetext{
Authors

Leonardo Baglioni, Sapienza Università di Roma, leonardo.baglioni@uniromal.it

Marta Salvatore, Sapienza Università di Roma, marta.salvatore@uniromal.it
}

To cite this chapter. Baglioni Leonardo, Salvatore Marta (2021). Andrea Pozzo e l'arte dei linguaggi scenici/Andrea Pozzo and the art of scenic languages. In Arena A., Arena M., Mediati D., Raffa P. (a cura di). Connettere. Un disegno per annodare e tessere. Linguaggi Distanze Tecnologie. Atti del $42^{\circ}$ Convegno Internazionale dei Docenti delle Discipline della Rappresentazione/Connecting. Drawing for weaving relationship. Languages Distances Technologies. Proceedings of the $42^{\text {th }}$ International Conference of Representation Disciplines Teachers. Milano: FrancoAngeli, pp. $179-196$. 